\title{
Description of the last instar larva of Trypoxylon (Trypargilum) albitarse Fabricius (Hymenoptera, Crabronidae) from Brazil
}

\author{
Sandor C. Buys \\ Departamento de Entomologia, Museu Nacional, Universidade Federal do Rio de Janeiro. Quinta da Boa Vista, São \\ Cristóvão, 20940-040 Rio de Janeiro, Rio de Janeiro, Brasil. E-mail: sbuys@biologia.ufrj.br
}

\begin{abstract}
The last instar larva of Trypoxylon (Trypargilum) albitarse Fabricius, 1804 is described and illustrated, based on one specimen collected in southeastern Brazil. This larva can be distinguished from other described larvae of the subgenus Trypargilum Richards, 1934 for the following combination of features: integument of the body with spines; labrum and epipharynx with sensillae; medio-apical and latero-basal portions of the epipharynx devoid of spines.
\end{abstract}

KEY WORDS. Immature, morphology, taxonomy, wasp.

RESUMO. Descrição da larva de último estágio de Trypoxylon (Trypargilum) albitarse Fabricius (Hymenoptera, Crabronidae) do Brasil. A larva de último estádio de Trypoxylon (Trypargilum) albitarse Fabricius, 1804 é descrita e ilustrada, com base em um exemplar coletado do sudeste do Brasil. Esta larva pode ser distinta de outras larvas do subgênero Trypargilum Richards, 1934 descritas pela seguinte combinação de caracteres: tegumento do corpo com espinhos; labro e epifaringe com sensilas; porções medio-apical e latero-basal da epifarge sem espinhos.

PALAVRAS CHAVES. Imaturo, morfologia, taxonomia, vespa.

Larval morphology of only a few species of the large genus Trypoxylon Latreille, 1796 is known (Williams 1919, SoIKa 1934, Maréchal 1936, Evans 1957, 1959, Yoshimoto 1964, Iida 1969, Asís et al. 1994, Buys 2003). This genus is usually split into two subgenera, Trypoxylon and Trypargilum Richards, 1934. Larvae of the following species and subspecies of the subgenus Trypargilum have been described: T. californicum Saussure, 1867 (Evans 1957, as T. arizonense Fox, 1891); T. clavatum Say, 1837 (Evans 1957, 1959); T. clavatum johannis Richards, 1934 (Evans 1957, 1959, in both as T. johannis); T. collinum Smith, 1856 (Evans 1959); T. collinum rubrocinctum Packard, 1867 (Evans 1957, 1959, in both as T. rubro-cinctum); T. lactitarse Saussure, 1867 (Evans 1957, 1959, in both as T. striatum Provancher, 1888); T. politum Say, 1837 (Evans 1957, 1959); T. spinosum Cameron, 1889 (Evans 1957); T. texense Saussure, 1887 (Evans 1959); T. tridentatum Packard, 1867 (Evans 1957, 1959).

Trypoxylon (Trypargilum) albitarse Fabricius, 1804 is widely distributed in South America (Amarante 2002) and it is conspicuous in southeastern Brazil. Herein the last instar larva of this species is described and illustrated.

\section{METHODS}

The techniques follow in general lines Evans \& LiN (1956). The head and the entire body of the larva were separately heated in $\mathrm{KOH}(10 \%)$ for about 15 minutes to eliminate the soft tis- sues. The head and the mouthparts were mounted in slides with glycerine. The number of punctures and setae on the genal areas on the left side of the head and of the right side of the head was put in the description separated by a slash. The palpi, galeae, and setae were measured at the base. The examined material and associated adults are deposited in the Museu de Zoologia da Universidade de São Paulo (MZUSP), São Paulo State, Brazil.

\section{RESULTS}

\section{Last instar larva (Figs 1-6)}

Body: White. Length $1.7 \mathrm{~cm}$; width $0.5 \mathrm{~cm}$. Intersegmental lines distinct. Pleural lobes developed, rounded, isolated, smaller on segments TII and TIII, absent on segment AX. Spines on integument with 7-15 $\mu \mathrm{m}$ long and 2-5 $\mu \mathrm{m}$ wide, different kinds of spines not distinguished. Integument with two kinds of setae without a detectable regular pattern of distribution: small setae with 6-12 $\mu \mathrm{m}$ long and about $2 \mu \mathrm{m}$ wide; large setae with 37-68 $\mu \mathrm{m}$ and 2-5 $\mu \mathrm{m}$ wide. Spiracles with 120-150 $\mu \mathrm{m}$ in diameter; not noticeably sculptured. Anus ventral.

Head capsule: Height about $1.7 \mathrm{~mm}$; width about $1.8 \mathrm{~mm}$. Coronal suture indistinct. Parietal bands unpigmented. Antennal orbits pigmented; $65 \mu \mathrm{m}$ wide and $55 \mu \mathrm{m}$ in height, with three sensilla distributed in a straight line. Antennal and frontal concavities lightly pigmented. Cephalic rugosity (small con- 

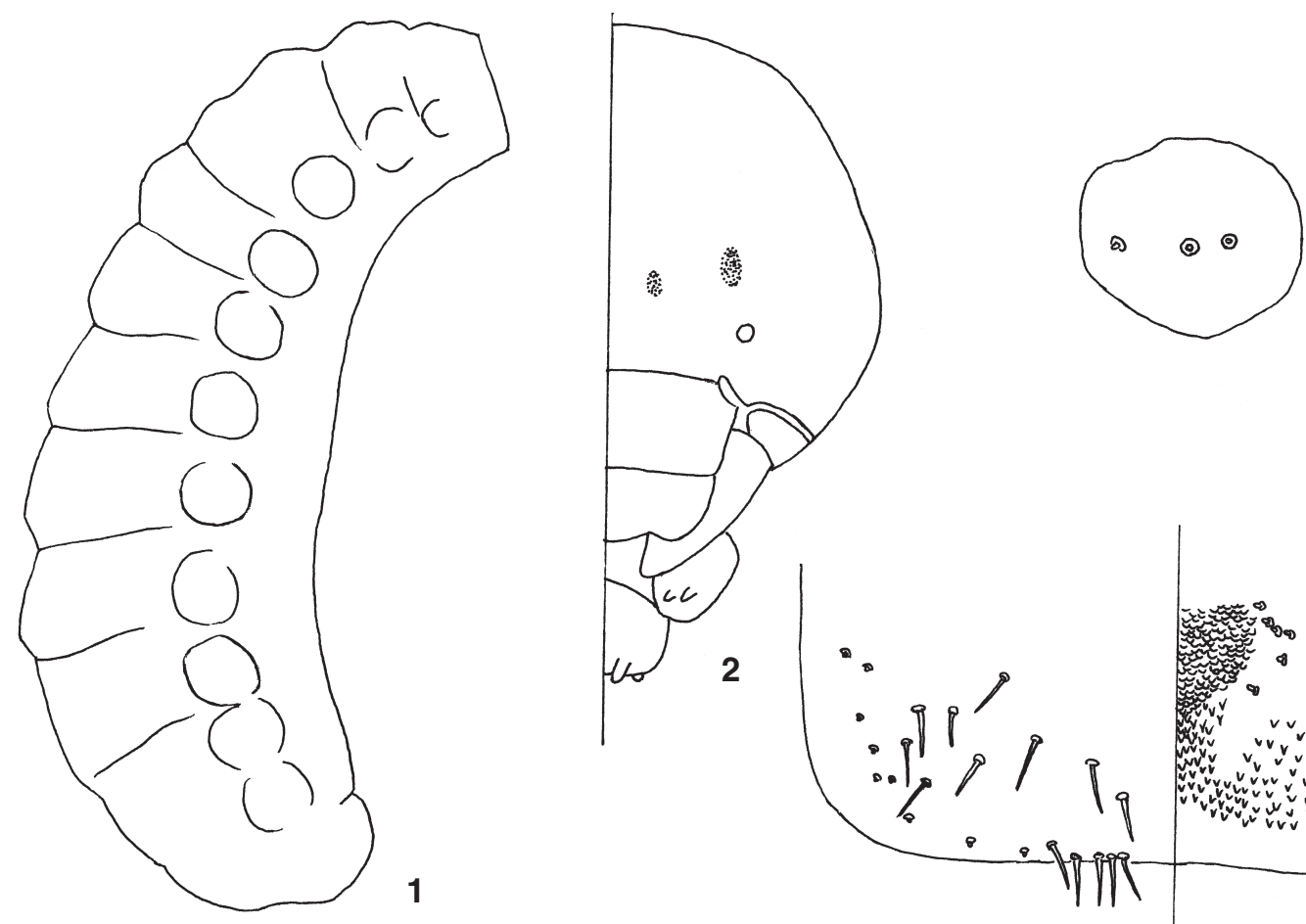

\section{3}
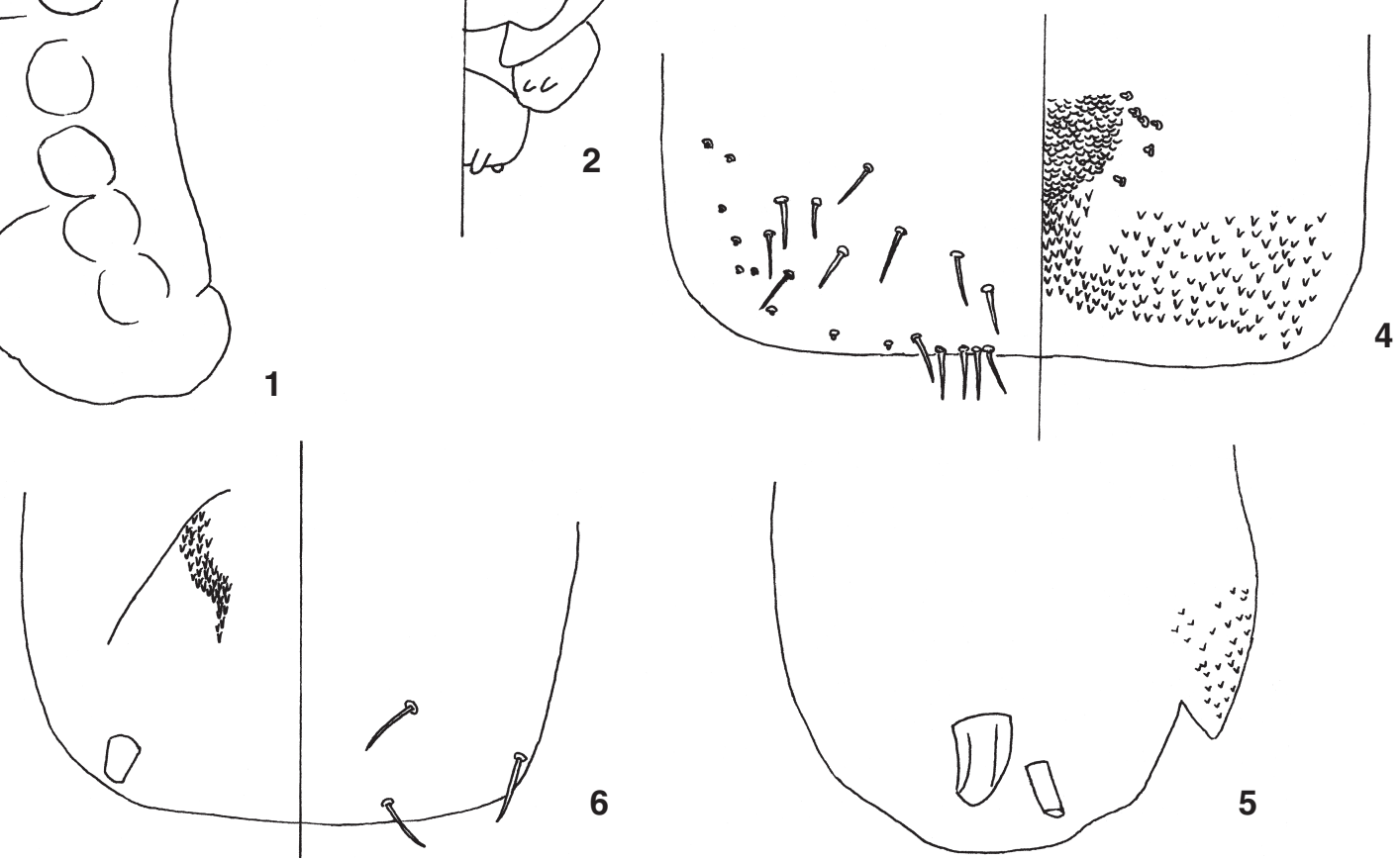

Figs 1-6. Last instar larva of Trypoxylon albitarse: (1) body without the head, lateral view; (2) head, frontal view; (3) antennal orbit, frontal view; (4) labrum and epipharynx, frontal view; (5) apical portion of the maxila, lateral view; (6) labium, dorsal and ventral views.

vexities on the integument of the coronal area of the head) weakly developed. Coronal area without punctures; with four setae (about $45 \mu \mathrm{m}$ long and $5 \mu \mathrm{m}$ wide). Frontal area with five setae (37-50 $\mu \mu \mathrm{m}$ long and 3-5 $\mu \mathrm{m}$ wide). Genal areas with about 40/38 punctures (5-9 $\mu \mathrm{m}$ in diameter); without setae. Clypeal area with about 10 setae $(55-60 \mu \mathrm{m}$ long and $5 \mu \mathrm{m}$ wide) and 12 punctures (about $8 \mu \mathrm{m}$ in diameter). Setae on the head without a detectable regular pattern of distribution. Pleurostoma partially pigmented, especially in the points of articulations with the mandibles; anterior tentorial arms unpigmented; hypostoma pigmented.

Mouthparts: Labrum quadrangular, $710 \mu \mathrm{m}$ in width and $400 \mu \mathrm{m}$ in height; without punctures; with 30 setae $(38-63 \mu \mathrm{m}$ long and $6 \mu \mathrm{m}$ wide) and about 26 basiconic sensillae with about $5 \mu \mathrm{m}$ wide. Epipharynx without pigmented areas; marginal, lateral and central portions with spines up to $10 \mu \mathrm{m}$ long, all the spines turned to the apex; a strongly papillose area basally on the central portion; about 12 basiconic sensilla near the papillose area. Mandibles pigmented, especially in apical portions and in mandibular articulations; with five teeth; 620 $\mu \mathrm{m}$ long; one basal setae (50 $\mu \mathrm{m}$ long and $5 \mu \mathrm{m}$ wide); strongly verrucose on the superior portion. Maxillae without pigmented areas; apical portion not papillose; with two setae $(55 \mu \mathrm{m}$ long and $5 \mu \mathrm{m}$ wide); spines basally on dorsal, ventral, inner, and external portions about $10 \mu \mathrm{m}$ long; maxillary palpi pigmented, larger on the base and slightly tapering toward the apex, 85 $\mu \mathrm{m}$ long and $50 \mu \mathrm{m}$ wide; galeae pigmented, approximately cylindrical, $48 \mu \mathrm{m}$ long and $25 \mu \mathrm{m}$ wide; lacinial area with 
scattered spines up to $8 \mu \mathrm{m}$ long, with an angular lobe distinct. Labium with $520 \mu \mathrm{m}$ in maximum width; a pair of small spinulose areas on the central portion, the spines up to $25 \mu \mathrm{m}$ long; ventral portion with six setae (38-45 $\mu \mathrm{m}$ long); labial palpi about $50 \mu \mathrm{m}$ long and $30 \mu \mathrm{m}$ wide. Spinnerets apically truncate, slightly longer than the labial palpi.

Examined material: Brazil, São Paulo: São Paulo (Campus of the Museu de Zoologia da Universidade de São Paulo); 27/ XII/1988; S.T.P. Amarante leg., one last instar larva with the mandibles worn.

\section{DISCUSSION}

The larva of T. albitarse differs from other known larvae of the subgenus Trypargilum (Evans 1957, 1959) for the following features: (1) integument of the body with spines (except from those of $T$. texense and T. clavatum johannis); (2) labrum with sensillae laterally; (3) epipharynx with sensillae medially (except from those of $T$. texense); (4) medio-apical portion of the epipharynx devoid of spines (distinguished only from $T$. lactitarse); (5) latero-basal portion epipharynx devoid of spines (except from those of $T$. californicum).

Some characters observed in the larva of T. albitarse, which apparently were not adequately treated in previously larval descriptions of Trypargilum, are remarked as follows, since apparently they are useful to the systematics of the subgenus. (1) Setae on the integument of the body were related in larvae of Trypargilum in the comprehensive papers by Evans (1957, 1959). Although this author commented about differences in the length of the setae among some species, he did not measure the setae. Therefore, comparisons with his observations are not possible. (2) Sensillae on the labrum were not previously found among larvae of Trypargilum (Evans 1957, 1959) and (3) sensillae on the epipharynx were mentioned only $T$. texense (Evans 1959). However, it is necessary to have caution with these observations, since small basiconic sensilla are easily confounded with pores or punctures. (4) Spines basally on the maxillae, as herein related in T. albitarse, were not found in larvae of Trypargilum (Evans 1957, 1959). Structures somewhat similar have been found in the inner portion of the maxilla of some larva of Sphecidae and bees (e.g. Buys 2005, Buys et al. 2004). It is possible that the basal spines on the maxillae had been overpassed in previously description of Trypargilum.

\section{ACKOWLEDGEMENT}

Sérvio Amarante has kindly lent me the studied material. The manuscript benefited from the useful comments of Celso Oliveira Azevedo.

\section{REFERENCES}

Amarante, S.T.P. 2002. A synonymic catalog of the neotropical Crabronidae and Sphecidae (Hymenoptera: Apoidea). Arquivos de Zoologia, São Paulo, 37 (1): 102-139.

Asís, J.D.; J. Tormos \& S.F. Gayubo. 1994. Biological observations on Trypoxylon attenuatum and description of its mature larvae and its natural enemy Trichysis cyanea (Hymenoptera: Sphecidae, Chrysididae). Journal of Kansas Entomological Society, Manhattan, 67 (2): 199-207.

Buys, S.C. 2003. Last instar larva of Trypoxylon (Trypoxylon) maidli Richards, 1934, with notes on one nest. Revista Brasileira de Zoologia, Curitiba, 20 (3): 447-449.

BuYs, S.C. 2005 Morphological studies on the last instar larva of Centris (Hemisiella) tarsata Smith from Brazil (Insecta, Hymenoptera, Anthophoridae). Spixiana, Munchen, 28 (2): 139-143.

Buys, S.C.; E.F. Morato \& C.A. Garófalo. 2004. Description of immature instars of three species of Podium Fabricius, 1804 (Hymenoptera: Sphecidae) from Brazil. Revista Brasileira de Zoologia, Curitiba, 21 (1): 73-77.

Evans, H.E. 1957. Studies on the larvae of digger wasps (Hymenoptera, Sphecidae) Part III: Philanthinae, Trypoxylinae, and Crabroninae. Transactions of the American Entomological Society, Philadelphia, 83: 79-117 + IX-XX.

Evans, H.E. 1959. Studies on the larvae of digger wasps (Hymenoptera, Sphecidae) Part V: Conclusion. Transactions of the American Entomological Society, Philadelphia, 85: 137-191.

Evans, H.E. \& C.S. Lin. 1956. Studies on the larvae of digger wasps (Hymenoptera, Sphecidae) Part I: Sphecinae. Transactions of the American Entomological Society, Philadelphia, 81: 131-153.

IIDA, T. 1969. Contributions to the knowledge on the sphecid larvae in Japan (Hymenoptera). Part I. Kontyû, Tokyo, 37 (3): 272-279.

Maréchal, P. 1936. Ethologie des Trypoxylon (Hym. Sphég.) et observations sur T. attenuatum Sm. Bulletin et Annales de la Société Entomologique de Belgique, Bruxelles, 76: 373-396.

Sorka, A.G. 1934. Etudes sur les larves des hyménoptères. Annales de la Societe Entomologique de France, Paris, 103: 337-344.

Williams, F.X. 1919. Philippine wasp studies. Bulletin of the Experimental Station of the Hawaiian Sugar Planters' Association. Entomological series, Honolulu, 14: 1-186.

Yosнiмото, C.M. 1964. Nesting activity and larval description of Trypoxylon (Trypoxylon) bicolor Smith (Hymenoptera: Sphecidae) in Hawaii. Pacific Insects, Honolulu, 6 (3): 517521.

Received in 21.XII.2004; accepted in 15.VIII.2005. 